\title{
Playing God? Synthetic biology as a theological and ethical challenge
}

\author{
Peter Dabrock
}

Received: 4 May 2009/Revised: 7 June 2009/ Accepted: 1 July 2009

(C) The Author(s) 2009. This article is published with open access at Springerlink.com

\begin{abstract}
In the ethical debate over synthetic biology the formula "playing god" is widely used in order to attack this new branch of biotechnology. The article analyses, contextualizes and criticises this usage with respect to the theological concepts of creation, sin and humans as created in the image of God. Against the background of these theological understandings an ethical corridor of how to responsibly cope with the societal challenges of synthetic biology is presented.
\end{abstract}

Keywords Synthetic biology - Playing God - Creation . Sin · Image of God · Responsibility · Systematic theology · Theological ethics

\section{Worries}

"Playing God"- this reproach has accompanied modern biotechnology from its very beginnings. Almost every step forward in research has provoked vehement protest against the disregarding of creation: anaesthesia against pain, the birth control pill, transplantation medicine and diagnosing brain death, stem cell research and genetic engineering and many more innovations were faced with this reproach (Ramsey 1970; Chadwick 1989; Coady 2009).

Whenever this formula is used, religious associations are supposed to be evoked in the recipients: it identifies particularly relevant issues, questions of ultimate concern, which must be handled with due respect. In a situation, in

\section{P. Dabrock ( $\square)$}

Philipps-Universität Marburg, Fachbereich Evangelische

Theologie, Lahntor 3, 35032 Marburg, Germany

e-mail: dabrock@staff.uni-marburg.de

URL: www.theologische-bioethik.de which mortal man sets about claiming tasks, functions or even the being of God, who is usually conceived as eternal, the illocutionary force of "playing God" becomes obvious: it encodes a reproach rather than praise. Considering the concept of "play", the latter would also be conceivable, at least theoretically and assuming an unbiased hearer. Usually governed by a pessimistic view of civilization, the phrase conveys that man in general or specific individuals have transgressed allegedly fixed limits that establish a certain order. If human beings try to conquer the position of the one who embodies the most fundamental difference from mankind, namely God, they are suspected of exceeding the limits of man and thus of responsible behaviour. Playing God arouses the suspicion of megalomania.

The secular philosopher of law Ronald Dworkin rejects this use of the expression "playing God" in biopolitical discourse (Dworkin 2000). He accuses everyone using this phrase of being intellectually and morally dishonest. Certainly, it is irritating to observe that the established differentiation between matters that must be humbly accepted and those that can be shaped by humans begins to blur. According to Dworkin, however, it is not a recent phenomenon, i.e. a phenomenon of the era of modern biotechnology, that humans have begun to rebel against seemingly hostile nature. By contrast, overstepping boundaries actually belongs to the very nature of man and biotechnology is qualitatively nothing new. Moreover, he asks whether there is anybody who does not profit from these very innovations, which we then criticize arrogantly in public debates. The accusation of playing God, from his point of view, serves as a repository for reactionary conservatives, who anxiously reject the principally nonrejectable cultural duty of man to shape the world.

The American theologian Willem B. Drees adds further theological aspects to Dworkin's interpretation of "playing 
God" (Drees 2002). He agrees with Dworkin that "playing God" is an indirect expression of strong unease. He attributes this to the observation that the undermining of oldestablished cultural structures does not only lead to changes in the image of man, but also in the image of God. One might argue that it is not surprising that these images correlate. Nevertheless, religious individuals cannot be reassured by the anti-religious assertion that images of God are mere projections of anthropology on the hereafter. They have to account for the way they keep up their confidence in God, who helps them to handle individual and social contingency. Just as Bonhoeffer in his famous prison letters (Bonhoeffer 1997), Drees finds that whenever this confidence is shaken, the "playing God"-reproach against modern technologies is based on an inadequate concept of God as a "God of the Gaps". As soon as such puzzles are solved, God is marginalized again - and those who entrench themselves behind the "playing God"-reproach in the discussion of modern technologies actually feel this. In order to avoid the challenge and to preserve one's own image of God and the usually associated cultural (moral, ritual and political) procedures, one turns against the new possibilities and its representatives with emphatically pronounced aggression. Even though this is effectively employed in image cultivation, the propagated ideals are not at all put into practice, which corresponds to Dworkin's predictions.

Even if one principally agrees to Dworkin's and Drees's criticism of the "playing God"-formula, one might still find some instances in which the reproach can be justified with respect to specific technologies. Perhaps, or even obviously, there are certain limits to seemingly unlimited scientific progress. Transgressing such limits is not only practically unwise, but ethically irresponsible. Two kinds of reasons can be formulated for an expectable or even unavoidable rejection: the technologies in question could be, following the terminology of ethics, consequentially irresponsible, i.e. their consequences would be unacceptable. In such a case, the risks are high and likely to arise. In another scenario, a technology could be deontologically reprehensible, i.e. certain duties would be violated and the actions themselves would have to be considered objectionable. Actions are categorized as reprehensible if, apart from continuing disagreements in specialized ethical discourse, the vast majority of people says: "You mustn't do that!"-e.g. torture. Especially in defining reprehensibility, religious and non-religious argumentations diverge. Nevertheless, as a rule, reference to deeply rooted cultural assets suffices to reach consensus on a general duty to refrain from such actions.

It is very remarkable indeed that the possibilities arising from one of the youngest branches of modern biotechnology, namely synthetic biology, have been faced with a concerted attack by "playing God"-critics. The use of this phrase is not limited to sanctimoniously disquieted debates anymore, but it can be encountered in many recent ethical publications on synthetic biology (e.g. ETC. Group 2007; Balmer and Martin 2008; Schmidt et al. 2008; Schmidt et al. 2009a; Bedau and Parke 2009). On the one hand, it insinuates unease about cultural implications. On the other hand, the authors do not deny the seriousness of the problem, since, in fact, synthetic biology might question the boundaries between the animate and the inanimate. Religious cultural traditions, however, define this as a divine privilege and even if one does not believe in God anymore, the guiding function of the religious motive for guarding this fundamental boundary is still widely appreciated. Therefore, the question of "playing God" is considered thoroughly even though the intellectual substance of the reflections varies.

\section{Synthetic biology—life 2.0?}

Why could the religious or pseudo-religious worry that this technology means "playing God" be utterly baseless? With regard to the history of science and technology, synthetic biology has certainly been a new and, particularly for religious people, a disquieting development. This can be traced back to the systematic linking of basic scientific research with engineering, which has lead to a paradigm shift. Of course, it is well known: Technologies suggested by basic research can actually be put into practice and several technical innovations work even before they are analysed and understood-both procedures are realized in present-day projects. What is particularly innovative about synthetic biology is that models originally developed for engineering are now used in order to understand and then reproduce the fundamentals of life. The results of current research are still fragmentary, concentrating on details. Nonetheless, this young field of research is driven by a revolutionary vision of science: Life is to be reconstructed from inanimate material. Believing the far-reaching promises (with their certainly not incidental commercial appeal), active substances for medical and pharmaceutical applications, but also for environmental care will be developed by means of these new organisms. The most tempting vision is designing new sorts of biofuel to replace fossil fuel.

The innovation of synthetic biology is not about creating new life. From time immemorial, this has been tried by diverse methods of breeding, which have been refined continuously and finally reached their peak in cloning. In the cultural memory of mankind, this form of biotechnology is commonly approved as normal and morally justifiable. Yet, using inanimate material for the production of entities fulfilling widely accepted criteria of life (namely metabolism, reactions to the environment, variability, i.e. evolutionary flexibility from generation to generation) 
would mark an ontological and cultural paradigm shift. Taking into account that the boundary between life and the inanimate plays a fundamental role in the governing and stabilizing power of the common sense and of many religions, it is apparent that any damage to this principle would be irreconcilable with these world views.

The heart of many religions, including biblical tradition, is touched when science questions the privilege of the deity or God to decide on the transitions between life and the inanimate. Hence, it seems for many religious people plausible to identify synthetic biology with a new and formerly unknown overstepping of this boundary. Instead of manipulating selected features of the genome as it is done in conventional gene technology, man sets about to create a creatio a novo. Correspondingly, Giovanni Maio and his team have lately published a report for the Swiss Federal Ethics Committee on Non-Human Biotechnology, in which they confirm that synthetic biology has lead to an alarming paradigm shift from homo faber to homo creator. The authors point out that the respect for life might be weakened if humans lay claim to the position of the sovereign creator (Boldt et al. 2008; cf. Boldt and Müller 2008). Under these circumstances, fierce ontological, philosophical, but also political and religious debates seem inevitable: Is artificial life real life? Do we have to prevent research in this field? Which consequences may arise from the possibility to produce life from inanimate material?

The specific challenge to theological ethics

In the young, but very dynamic ethical debate about synthetic biology (Schmidt et al. 2009b) and expectable cultural conflicts, theological ethics should, in my opinion, fulfil the function of the sober-minded observer: Does research, by establishing such technologies, consciously or subconsciously introduce changes in the image of man? Does it jeopardize and (irreversibly) overstep carefully defined boundaries? Are religious conceptions or practices affected? Therefore, the "playing God"-motive belongs to the issues that must be included in ethical considerations. Regarding the often unreflective use of the traditionally religious formula, there is a need for establishing a constructive and critical distance to this phrase and its (mis-) use. For this purpose, the compatibility of the phrase within Christian tradition, ecclesiastical procedures and sources must be examined. The results will help to decide on the usefulness of the formula in public debates. In the following, the inner perspective of theological reflections is discussed first. Then, the stances of the academic and nonacademic public and answers will be introduced and the question will be answered whether the development of new organisms from inanimate material is consistent with the vocation of man or whether it means interfering in the domain of God. In other words: Does man act as co-creator Dei (when realizing the optimistic vision of a creatio $a$ novo) or does he fundamentally contradict his place in God's creation and act, in theological terms, sinfully? This question does not cover the entire ethical explosiveness of synthetic biology. The often debated issues of biosecurity, biosafety and access, however, are treated in other contributions to this volume. Thus, I will concentrate on the specific challenge for theology: Which impacts does the sudden possibility of manipulating the boundary between life and the inanimate nature have on our human selfconception and our image of God?

\section{Synthetic biology: participation in creation or sin?}

The range of different interpretations

There are several possibilities for a theological-historical interpretation of the creation of life from inanimate material in religious contexts. Theoretically, we might re-identify an adoption of the famous dominium terrae (the divine commission to humankind to rule over the earth according to Gen 1:28). Assuming a favourable view on modern biotechnology, one might refer to human intellect. This gift might place the obligation on man to participate in the new creation, the Kingdom of Heaven. In the late nineteenth century, scientific progress was identified with the striving for the Kingdom of God. Comparable ideas of progress can be encountered in recent American systematic theologies by Ted Peters (2008) or Anne Foerst (2004): Man's position is very close to the co-creator Dei, as he systematically continues God's creation. But is this in tune with the theological concept of creation?

At the other end of the scale, the sceptics of this technology rather rely on pretended biblical evidence when judging on synthetic biology and its relation to the divine privilege of creation. The motive "God is the Lord of life" resounds throughout the Old Testament, especially in Genesis 3:22 and later in the statement that all blood belongs to the property of God, who gives and also takes it (Gen 9:4). If life in general belongs to God, it is argued, man is not authorized to question the distribution of properties. Apart form the obvious, performative contradiction (noting that humans have always been deciding on life and non-life), we have to ask whether the manipulation of the biosphere is on the same level as God's creation.

'Creation'—-systematic theologically

Hermeneutic reflection is a reliable way to describe the emphatically claimed continuity of divine and human acting on the one hand, and, on the other, the allegedly 
convincing irreconcilability of the biblical testimony of God as the creator and biotechnology. The concept of creation and particularly its possibilities and limits compared to these two other approaches must be considered. Hence, the question has to be settled whether specific, isolated human actions are qualitatively similar to God's creative doing and may therefore affect or replace it.

Correspondingly, the notion of creation must be clarified. The fruitful interaction of systematic theology, exegesis and biblical theology has led to an insight which is highly relevant in our context: Creation is not simply a given fact, but it is determined by a specific interpretation of the world. Against the "it was good" (Gen 1), which is not always experienced, a hermeneutic perspective helps to establish an encouraging counterpoint-existential, praising, but also complaining. The insights gained by this approach go beyond creation as a given fact and trace out ways for an adequate coping with the world in which we live. Being allowed to interpret something from the angle of belief may result in questioning common social and scientific conceptions.

The perception of something as being created cannot be fathomed by human consciousness itself, but it paves the way for the believer to a new interpretation of something that exists. Something is perceived as something (namely as creation, i.e. from the believed perspective of God). This is how the world, or its status as being given, addresses us or presents itself to us as a parable — an idea contributed by Oswald Bayer and Christian Link (Link 1976; Bayer 1986). The concept of something 'being given' is highly ambivalent. Applied to our topic, the given world (i.e. in our case nature) does not give us any hint as to how we are supposed to handle it, unless we believe in creation. The handling of the world is oriented at cultural patterns of interpretation, including, besides the concept of creation, the depiction of the world as a stage for human activity or as a transitional stage into the sphere of ideas.

\section{Misconceptions of creation}

Knowing that creation is not just a given fact, but that it explains the often opaque conditions of nature and world, it must be clarified in which ways 'creation' determines the actions of man. Where could limits be defined, which might possibly restrict human actions?

Firstly, we should consider which aspects of the world are not explicitly addressed by the conception of 'creation':

Whoever perceives the world as a product of creation does plead for a strict separation of world and God. Creation and pantheism are incompatible. Creation demands from the believer a strict differentiation between creator and creature. From the perspective of Christian faith, this difference cannot be overcome by man, but exclusively by
God's initiative arising from his free, loyal affection. Believing in the concept of creation excludes the thesis that God has turned away from the world he created. This also explains the irreconcilability of deism and the idea of a creatio continua within the Christian doctrine of creation. The same holds for the speculation that instead of a benevolent creator, a demiurg, i.e. an inferior god, created the world. For this reason, Manichaean Gnosticism contradicts the biblical interpretation of the world as a creation.

\section{Creation as original and preserving loyalty of God}

Against the background of these definitions, creation as a model of interpretation, which is only available for the believer, paves the way for further perceptions of the world as a parable (Link 1991). Since the middle of the twentieth century, there have been great debates on the relation of creation and history in various schools of Old Testament research. They have shown in unison that through all traditions, 'creation' is not primarily linked to the past, e.g. in order to utilize it for a scientific explanation of the cosmogony of the world. On the contrary, Genesis 1-3 and Rev 21-22 are used as a frame in the Christian bible to illustrate the connection between past and future, of origin and redeeming eschatological fulfillment. The composition of the bible suggests that past and future, origin and hope are supposed to function as a frame for our understanding of the present (Moltmann 1985).

What does the interpretative category 'creation' say about the world by talking about God as the creator? Whenever God creates something, it is something opposite to him. He restricts himself, but loyally and reliably grants room and time to it. For God's self-restriction and loyalty to offer a partner different from him time and room, i.e. for the willingness to create, the Hebrew bible has a special word without any known analogies: bara. It is only attributed to God. If God is referred to as bore, this fundamental issue is addressed, i.e. the creation of the world as a whole, the ability to lovingly create an opposite and the will to infinitely preserve it in its finiteness. These are exclusively divine attributes - a human being can impossibly be a bore in this very sense (Kesser 2008). In my opinion, the topos that all blood is the property of God symbolizes, beyond all mythological language and ritualizing practices, precisely this difference: It is the categorical difference between God's creative doing and human acting, which man cannot neutralize on his own. This idea of the creatio ex nihilo, which was added to biblical tradition relatively late, points to this purely divine, initial and continuing creativeness. 'Creation' in systematic theological terminology as opposed to every-day language is not a single act. Rather, it is radical, the root of all, the divine 
love that creates and preserves life as a whole-something that man is obviously not capable of.

Conclusions for the research question

How can we react to the statement based on the allegedly literal interpretation of the bible that "something like synthetic biology attacks the divine domain as man tries to breathe life to something inanimate"? Taken that the considerations on the meaning of God's creation above are correct, such theses can be rejected as unsound: Man can principally not act like God. Drawing upon theological conceptions of creation could therefore be one way to defend oneself against the "playing God"-reproach in the controversy about biotechnologies including synthetic biology. It might even be argued that the worry that man could manipulate God's creation reveals a fundamental misconception of God. Mistakenly and inadequately, God is seen as fighting the competition with man for the job of a super-engineer (Evers 2009).

\section{Synthetic biology as a sin?}

On the difficulty of declaring isolated deeds as sins

This intermediate conclusion on the "playing God"reproach shows only one side of the coin: If humans cannot be co-creatores Dei, they cannot even pretend to be so, even if they are all appointed to be cooperatores Dei (cooperators of God), which was an undisputed thesis among the reformers. Doesn't synthetic biology express the human wish of being God, arrogance, hubris, a destructive fantasy of omnipotence? Are such actions not sinful?

In Protestant theology, the identification of isolated deeds as sins is widely regarded as a difficult issue-with all ambivalences resulting from this (Gestrich 2003). Undoubtedly, there have always been experiments and situations in which not only the original sin of man, but an additional sin originating from a specific decision made by an individual or an organization has been committed. From the stance of the reformers, sins are multifarious and hard to identify - good deeds are done in the name of the evil and vice versa. Luther's example of the good tree, which carries good fruits, does not deny that even in the justified, the power of $\sin$ is still at work. There is no analytically necessary connection between being and acting, but much uncertainty.

Even if the permanent failure of man to live up to his god-given position in creation is interpreted as an original sin, it is virtually impossible to track down the exact deeds in which this original sin manifests itself. The difficulty of identifying sins is further elaborated on in Karl Barth's impressive theological model of sin. Barth demonstrates human failure by contrasting man's behaviour with the life of Jesus Christ, who, by ideally fulfilling the divinely determined function of man in creation, brought about reconciliation. According to this Christian model of reconciliation and the theology of sins deduced from it, sins are situation-dependent and may not only manifest themselves in arrogance, but similarly in lethargy or lies (Barth 1956-1962).

Applied to the issue of synthetic biology, the argumentation of both, supporters and opponents, arouses suspicion. Those who are ready to develop high-risk applications of this technology might be blamed for their fantasies of omnipotence, depicting the wish to gain control over life. In such a case, any sense of respect for life as something given would be lost. Yet, those who call for a ban on synthetic biological research might be blamed for their lethargy, despondency, and for shirking responsibility. After all, we cannot rule out the possibility that, assuming concrete situations in life, neglecting research could have grave consequences, e.g. with regard to resistant types of viruses.

A revealing contrast: imago Dei as undeniable responsibility

Instead of identifying an action or a whole field of research as sinful, we must take more notice of imago Dei as an honouring of the human being, which can be read from God's affection in his covenant and from the life of Jesus Christ. As a term of theological anthropology, imago Dei does not label man as the chosen creature that possesses divine qualities. Unlike animals, human beings are equipped with the skills of reflection, of forming concepts and with a potential for self-distance, traditionally referred to as reason. Nevertheless, according to Protestant theology, these qualities are not the core of the noble category 'imago Dei' (Dabrock et al. 2004). Rather, it stresses the ennoblement of man through the direct address by God. This status of being addressed by God is granted to man-neither can he actively acquire it, nor is he principally entitled to receive it. This circumstance, however, is inextricably linked to obligations: From the perspective of Christian tradition, God charges man with the responsibility for his fellow humans and all other creatures and may even demand basic equality among men, which is not naturally given for various worldly reasons.

The noble quality of the imago Dei is another, religious hermeneutical model for critically reviewing human actions. Despite his failure, which he is well-aware of, man is called to act in accordance with his status as imago Dei. The dominium terrae is, indeed, realized beyond Eden, i.e. under the condition of $\sin -$ or in non-theological terms: 
under the condition of finitude and failure. Consequently, human life is always marked by violence. This is, however, not justified by the divinely imposed duty to exercise stewardship over creation. Against the background of the imago Dei, this duty must not be misunderstood as a permission to ruthlessly oppress others, but it calls for a responsible integration of man into the community of all creatures. Under these circumstances, the unique responsibility of man is obvious. This insight shows that, in biblical tradition, responsibility is a strongly anthropocentric term. It is part of this responsibility to differentiate between the beneficial and the inimical. This differentiation must be independent from one's own benefit and be governed by the reverence for the unity of life in its biodiversity. Doing justice to the imago Dei thus involves paying tribute to the loyalty of God as the creator despite all setbacks, i.e. in theological terms, sinfulness, which manifests itself in arrogance, lethargy and lies.

\section{Conclusions for our research question}

It can be concluded that synthetic biology, per se, is not sinful—which, by the way, holds for nearly all human activities. Rather, research and applications in this field may, just like any other activity, become misled by the power of sin and result in failure. Whether that is the case or whether human beings sinfully utilize new technologies, respectively, can be evaluated and understood by considering the implications of the imago Dei-the specifically human status, which, unimpeded by sin, is or should be the driving force for a responsible commitment to creation. ${ }^{1}$

The considerations above have shown that synthetic biology as such does not mean "playing God", since the power to create (in the strict sense of bara) is exclusively divine and cannot be claimed by human beings. Similarly unfounded is the suspicion that this branch of science marks the striking failure of man to accept his position and duties within creation. There are many conceivable situations in which non-compliance with God's will occurs. The identification of human failure or sinful behaviour is very complex and cannot be facilitated by principally condemning specific, isolated deeds or research disciplines. Such a procedure would have to be based on very convincing reasons. It would have to endanger, obviously and intrinsically, the existence of humanity or its natural resources or the technology would have to show an alarming potential for misuse. Nevertheless, even if such conditions of an intrinsic "sinful deed" were not met, synthetic biology should not obtain a carte blanche, as

\footnotetext{
1 Which ethical consequences must be drawn from this approach will be outlined in the following chapter.
}

human actions have to be governed by the role model of a gentle and respectful handling of creation.

\section{Perspectives of theological ethics on synthetic biology-seven theses}

How can the results of the theological examination of our problem-i.e. synthetic biology neither usurps the divine domain, nor is it a sin, nor an ethically unproblematic issue- be transferred to the public and pluralistic debate on synthetic biology?

I will summarize my reflections about the topic in seven theses. Overlappings of theological statements with nontheological remarks do not indicate a deficit in theological reasoning. Theological ethics does not isolate from public reasoning, but vividly contributes to it (Thiemann 1996). Even the assumption that reference to God lays the foundations for understanding the nature of man and his actions does not keep theology from profiting from a primarily non-religious debate. This might turn out to foster a fruitful exchange of arguments between representatives of different world views and religions, which is supposed to lead to a consensus on how to use synthetic biology in compliance with relevant conceptions of 'the good'. One should, however, not be deluded by the fallacy that public reasoning on responsible synthetic biological research and its applications could work without any reference to normative and evaluative preconditions. This misinterpretation directly leads into two traps: firstly, it obstructs our sense for hidden assumptions-a drawback we cannot afford in controversial discussions. Secondly, there is the danger of losing one's motivation for acting with foresight, if human acting in general becomes disconnected from constructions of human identity and from the sense for the meaning of life. It is exactly these functions that are lie with theological ethics, i.e. accompanying public reasoning and relating the issues in question with the sources of meaning for human life, which make it an indispensable discipline in future debates (Dabrock et al. 2004). Against this background the following seven theses must be read:

1. Synthetic biology is liable to attract scandals on the one hand and to inspire fantasies of omnipotence on the other. This is due to the fact that it is on the point of breaking through a boundary deeply rooted in human cultural memory by penetrating into a domain that is believed to be exclusively reserved to the divine.

2. This quasi-religious misconception in both camps can be counteracted and limited by systematic theology and theological ethics in demythologizing the assessments of synthetic biology mentioned above. Theological concepts of creation and sin show that this field 
of research does not conquer an allegedly sacrosanct, divine domain. Nor can we brand this technology per se, i.e. deontologically, as being more reprehensible than any other conceivable technology, human action or institution.

3. If we are not willing to grant a carte blanche to synthetic biology, but rather choose to orient ourselves at the role model of preserving ecological variety, we have to consider the following aspects: The risks of all known and all future biotechnologies can only be evaluated with regard to their durability, their exact purpose, their social relevance and, finally, to their level of safety and security. We have to answer the question about the probability of unintended damage or harm and also of misuse. How extensive is the manipulation? Which established or establishable possibilities of intervention are available to react to unexpected developments in authorized projects?

4. Wherever such questions are supposed to be answered concretely, it seems wise neither to condemn nor to welcome synthetic biology in general. Rather, we are asked to apply consequentialist criteria to every single synthetic biological research project or application to find out whether it is responsible and thus justifiable.

5. Nevertheless, the ethical challenge of synthetic biological projects is not completely determined by its expectable consequences and side effects. The general public has a right to question every discipline or branch of research as to its social and ecological compatibility. Criteria such as social and ecological sustainability, preservation of biodiversity, the specific network underlying a system and reversibility of decisions are important indicators for the ethical (il-) legitimacy of a specific project. It is hardly surprising that these criteria, which are largely shared by theological and non-theological ethics, are themselves open to interpretation. Once caught up in the machinery of political decision making with its legal restrictions, these initial considerations will be varied and transformed. In this situation, theological and non-theological ethicist must keep a critical eye on these transformations. Such mechanisms of power which operate beneath the surface must be uncovered and made public. Common attitudes like spontaneous risk-taking or reactionary tendencies are not to be identified with religion. A certain degree of sensitivity for such non-moral ways of interpretation prevents rash moralizing-and warning against this also belongs to the responsibilities of ethics.

6. In societies marked by the mass media, exaggerated expectations, both optimistic and pessimistic, of synthetic biology as a new field of research can be encountered. The societal system of media works according to the code 'attention/non-attention'. This code is not identical to the differentiation 'true/untrue'. For this reason, it is not only absolutely legitimate, but worth supporting that an intensive public debate about these new technologies is initiated and realized. If traditional images of man, the world and of God are questioned, if people are challenged to modify their ideas, there is too much at stake and even more to discuss.

7. To these debates, theological ethics will not only add the above-mentioned dogmatic or religious hermeneutical perspectives. The idea of principal public participation in all social issues, which ensues from human dignity and the granting of priority to the potentially worse-off, prompts theological ethics to intensify exactly those discussions, which might involve fundamental irritations. Especially the urgency of the question what life actually is, might be increased by synthetic biology. When noticing, however, that the reproduction of the simplest bacterium is extremely difficult if not impossible, people might want to pause in amazement about the magnificence and complexity of nature-or creation, from the perspective of the believer.

Conflict of interest The author declares that he has no conflict of interest.

Open Access This article is distributed under the terms of the Creative Commons Attribution Noncommercial License which permits any noncommercial use, distribution, and reproduction in any medium, provided the original author(s) and source are credited.

\section{References}

Balmer A, Martin P (2008) Synthetic biology. Social and ethical challenges. An independent review commissioned by the Biotechnology and Biological Sciences Research Council (BBSRC). http://www.bbsrc.ac.uk/organisation/policies/reviews/scientific areas/0806_synthetic_biology.pdf. Accessed 30 April 2009

Barth K (1956-1962) Church Dogmatics. The doctrine of reconciliation, vol 4. T \& T Clark, London

Bayer O (1986) Schöpfung als Anrede. Zu einer Hermeneutik der Schöpfung. Mohr, Tübingen

Bedau MA, Parke EC (2009) The ethics of protocells. Moral and social implications of creating life in the laboratory. MIT Press, Cambridge

Boldt J, Müller O (2008) Newtons of the leaves of grass. Nat Biotechnol 26:387-389

Boldt J, Müller O, Maio G (2008) Synthetische Biologie. Eine ethisch-philosophische Analyse. http://www.geneticresearch.ch/ downloads/EKAH_Synthetische_Biologie.pdf. Accessed 30 April 2009

Bonhoeffer D (1997) Letters and papers from prison. The new greatly enlarged edition. Touchstone, New York

Chadwick R (1989) Playing God. Cogito 3:186-193 
Coady CAJ (2009) Playing God. In: Savulescu J, Bostrom N (eds) Human enhancement. Oxford University Press, Oxford, pp 155180

Dabrock P, Klinnert L, Schardien S (2004) Menschenwürde und Lebensschutz. Herausforderungen theologischer Bioethik. Gütersloher Verlagshaus, Gütersloh

Drees WB (2002) "Playing God? Yes!" Religion in the light of technology. Zygon 37:643-654

Dworkin R (2000) Sovereign virtue. The theory and practice of equality. Harvard University Press, Cambridge

ETC Group (2007) Extreme genetic engineering. An introduction to synthetic biology. http://www.etcgroup.org/upload/publication/ 602/01/synbioreportweb.pdf. Accessed 30 April 2009

Evers D (2009) Leben machen. Unser Spiel als Schöpfergott. In: Pernkopf E, Rauchenberger J (eds) Wissenschaften-Machenschaften. Gespräche zwischen Forschung und Öffentlichkeit. Königshausen \& Neumann, Würzburg, pp 89-103

Foerst A (2004) God in the machine. What robots teach us about humanity and God. EP Dutton, New York

Gestrich C (2003) Peccatum. Studien zur Sündenlehre. Mohr, Tübingen

Kesser H (2008) Kreative Schöpfung-Kreativität Gottes. Überlegungen zum Spannungsfeld von Schöpfung und Evolution. In: Klose J, Oehler J (eds) Gott oder Darwin? Springer, Berlin, pp $27-58$

Link C (1976) Die Welt als Gleichnis. Studien zum Problem der natürlichen Theologie. Kaiser, München
Link C (1991) Schöpfung. Schöpfungstheologie angesichts der Herausforderungen des 20. Jahrhunderts. Gütersloher Verlagshaus, Gütersloh

Moltmann J (1985) God in creation. A new theology of creation and the spirit of God. The Gifford lectures 1984-1985. Harper \& Row, San Francisco

Peters T (2008) Proleptic ethics vs. stop sign ethics. Theology and the future of genetics. Journal of Lutheran Ethics 8. http://www.elca.org/ What-We-Believe/Social-Issues/Journal-of-Lutheran-Ethics/Issues/ February-2008/Proleptic-Ethics-vs-Stop-Sign-Ethics-Theologyand-the-Future-of-Genetics.aspx. Accessed 30 April 2009

Ramsey P (1970) Fabricated man. The ethics of genetic control. Yale University Press, New Haven

Schmidt M, Torgersen H, Ganguli-Mitra A, Kelle A, Deplazes A, Biller-Andorno N (2008) SYNBIOSAFE e-conference: online community discussion on the societal aspects of synthetic biology. Syst Synth Biol 2:7-17. doi:10.1007/s11693-008-9019-y

Schmidt M, Ganguli-Mitra A, Torgersen H, Kelle A, Deplazes A, Biller-Andorno N (2009a) A priority paper for the Societal and ethical aspects of synthetic biology. Syst Synth Biol (this issue)

Schmidt M, Kelle A, Ganguli A, de Vriend H (2009b) Synthetic biology. The technoscience and its societal consequences. Springer Academic Publishing, Vienna

Thiemann RF (1996) Religion in public life. A dilemma for democracy. Georgetown University Press, Washington, DC 